\title{
“COMMODIFYING” CHILDREN: THE IMPACT OF MARKETS IN SERVICES FOR CHILDREN IN THE UNITED KINGDOM ${ }^{1}$
}

\author{
Stephanie Petrie
}

\begin{abstract}
This paper is concerned with the impact on children's health and wellbeing resulting from the move from the Welfare State to welfare markets and explores the political trajectory that stimulated this sea change in U.K. welfare. Two services, child protection and children's day care, are examined to highlight how the separation of purchasing services from providing them have "commodified" children who have become objects with a use-value in commercial exchanges in internal or external markets. The paper concludes with an overview of the impact of "austerity" policies that exclude many children from welfare markets entirely and considers the consequences for the children of the U.K.
\end{abstract}

Keywords: United Kingdom, Welfare State, welfare markets, child protection, day care, austerity

Stephanie Petrie, Ph.D., C.Q.S.W., H.C.P.C., is Honorary Senior Research Fellow the School of Law and Social Justice, University of Liverpool, Eleanor Rathbone Building, Bedford Street South, Liverpool, United Kingdom, L69 7ZA. Telephone: +44-151-794-3015. E-mail: Spetrie@liverpool.ac.uk

\footnotetext{
${ }^{1}$ United Kingdom refers to the countries of England, Scotland, Wales, and Northern Ireland. Great Britain refers to England, Scotland, Wales, and their associated islands. Britain refers only to England and Wales and associated islands. The British Isles is a geographical term referring to the islands of Great Britain and Ireland including their $5000+$ small islands.
} 
It has been argued for some time by legal and medical ethics theorists that children have been "commodified" in relation to the transnational trade in adoptable children, surrogacy, and cloning (Baird, 1996; Yngvesson, 2002; Shuster, 2003; Spar, 2006). Recent controversies in Australia about commercial surrogacy and the welfare of children conceived for payment have now generated widespread concern (The Telegraph, 2014). It is easy to see in relation to these market transactions how children have acquired a use-value and are commodities in commercial exchanges.

This paper argues, however, that the shift from the Welfare State to welfare markets in the United Kingdom also commodified children. Services are no longer underpinned by the legislative principle of universal benefits of right. This principle has been replaced by laws and policies designed to target those most "in-need" in a context where legislative barriers to state provision have been enacted and out-sourcing to the "for-profit" sector encouraged. The "needs" of children have been codified in assessment templates in order to be quantified, costed, and contracted within a given timescale. It is not surprising, therefore, that children in welfare markets became objectified, problematised, and passed from provider to provider without continuity. In short, they have become commodities with cost/revenue implications.

Evidence is now emerging that the consequences of distributing services in this way at a time of economic recession exclude many children in need from welfare markets entirely. Child poverty has increased exponentially (National Children's Bureau [NCB], 2013) and a deficit model of children has emerged as the dominant reason why some were not treated humanely or protected from abuse and exploitation (Matthews, 2014; Rochdale Borough Safeguarding Children's Board [RBSCB], 2013). These children are, in effect, discarded as having little social value. This paper will explore the political trajectory that has shaped the economic character of welfare in the U.K. and led to the demise of the Welfare State and imposition of welfare markets before exploring in detail the operation of markets in child protection and children's day care services. Evidence emerging about the state of the nation's children will follow. The paper will conclude by considering the implications for the future health and well-being of children in the U.K.

\section{From the Welfare State to Welfare Markets}

The post-World War II (WWII) political settlement of the late 1940s in the United Kingdom was designed to resolve social antagonisms and form the basis for societal harmony; it became known as the Keynesian Welfare State (Burden, Cooper, \& Petrie, 2000). The Welfare State was brought about by a series of Acts stimulated by the Beveridge Report (Beveridge, 1942) and influenced by the economist John Maynard Keynes who argued for an economy managed by government through state expenditure in order to ensure full employment and protect citizens from the boom and bust cycles of "free markets". A high level of state-provided universal health and welfare services - from cradle to grave - paid for through taxation was part of this post-war settlement. Most of the legislation came onto the statute book between 1945 and 1950 during the first post-war Labour government. Nevertheless when the Conservatives returned to power in 1951 they were also committed to Keynesian full employment and the Welfare State - a post-war consensus in which welfare policies were "beyond” party politics.

The political commitment to a high level of collective societal responsibility for all children led to comprehensive child nutritional and health services whatever parental 
circumstances. Children were conceptualised as social assets upon which the future well-being of the nation would be founded. Substantial research had shown that poor nutrition and low income correlated with educational underachievement and school-based provision (alongside the wider NHS and fiscal benefits) was established to alleviate this problem. For example, within a short time following the end of WWII, all children received in school free milk, meals, and additional nutritional additives and had the benefit of school medicals, dentists, and nurses. Although there were many debates about the differentiation of roles and responsibilities within and between the NHS and other public sector services and some key reorganisations, particularly following the Seebohm Report of 1968, all major political parties supported the Welfare State for many decades notwithstanding significant critiques from the Right and Left (Friedman, 1962; Williams, 1989). The concept of collective responsibility for children began to be undermined, however, from the early 1970s, when some universal state services for young children were, for the first time, regarded as unnecessary. Margaret Thatcher, as Education Secretary in the government of Edward Heath, removed free school milk from the over-sevens in 1971 in order to meet government pledges on tax cuts.

The advent of the first Thatcher government in $1979^{2}$ ushered in an increasing change in political attitudes as to the role of the state in promoting the health and well-being of children. The post-war economic boom ended in the 1970s and the New Right gained power under Thatcher in part due to a sustained economic, political, and moral critique of the Welfare State (Burden et al., 2000). The Welfare State, it was alleged, created welfare dependency and led to costly, inefficient public sector services to the detriment of all citizens. Consequently, Compulsory Competitive Tendering (CCT) by local authorities (local government bodies) became mandatory in 1981 for such services as rubbish collection. Under CCT (now transformed into Best Value and Social Value by subsequent legislation in 1999 and 2012), state providers had to compete for state contracts with suppliers from the private and third sectors and a similar model was finally imposed on health and welfare services for adults by National Health Service and Community Care (NHS and CC) Act 1990. A new law for children, the Children Act (CA) 1989, was being implemented at the same time and was designed to unify all children's legislation, apart from adoption, under the same principles, orders, and courts. The overriding principle was that the child's welfare should be the paramount consideration in any court proceedings affecting their welfare (Part I). A new concept of "child-in-need" (Part III, section 17) was to be the passport to state provided or purchased services and the state acquired a duty to enable provision by others - at that time understood to be aimed at increasing the role of the third sector as the activities of the "forprofit” sector in children's services at the beginning of the 1990s was negligible.

The CA 1989 did not impose by statute the same market requirements on local authorities as the NHS and CC Act 1990, but the political, organisational, and resource context influenced the way in which the legislation was implemented. Consequently many local authorities simply organised children's services along the same lines resulting in an increase in the role of private sector, internal and external markets between assessors of "need" and providers of services, and the introduction of cost considerations at the individual level when professional assessments of need were made. The ideological position of the New Right then in power, informed by neo-liberal economics, created the conditions which ensured that the market framework, imposed on services for adults by the NHS and CC Act 1990, would also emerge in services for children despite there being no legal duty to do so. The impact on

\footnotetext{
2 Thatcher governments: 1979-1983; 1983-1987; 1987-1990.
} 
services for children of this paradigm shift consolidated when neo-liberal economic ideas began to dominate the national and local political landscapes of all major political parties.

The landslide victory of New Labour under Tony Blair ${ }^{3}$ in 1997 brought an increased commitment to markets in the public sector. As spokesperson for New Labour in 1998, Peter Mandelson stated that the mission of New Labour was to "move forward from where Margaret Thatcher ended” rather than dismantle her government's policies (Burden et al., 2000, p. 251). New Labour's project for welfare, framed within a market paradigm, was the redistribution of opportunity rather than income, with a focus on citizen responsibilities as well as citizen rights. The state was to be a commissioner and regulator of services rather than a provider and government strategy was to impose on local authorities a complex, heavily monitored framework of performance indicator targets for children combined with the availability of significant funding programmes such as Sure Start (Glass, 1999) for community-based preventive services. The extension of markets into the public sector and management by performance indicators led to a positivist approach to the assessment of children's needs. Using targets created a process of objectification by codifying and quantifying "needs" against which children were, and indeed are, ranked and prioritised, thus turning children in contractual terms into commodities (Petrie \& Wilson, 1999; Petrie, 2010). The commodification of children, with all the attendant consequences of inflexible, impersonal, fragmented, and shortterm services, has become entrenched with the subsequent growth of "for-profit" sector service provision.

Since 2010 this has been accelerated by a seismic shift in political configuration, with the first coalition government in post-war times (between the Conservatives and LiberalDemocrats), and "austerity" policies following the global economic crisis that began in 2008. Financial speculation and the subsequent collapse of the housing market in the United States in 2006 caused a global credit crunch affecting many countries. In response "austerity” policies have been adopted by the U.K. among others, and the entirety of the European Union is now facing political and economic turmoil affecting its very future as the impact of "austerity" bears down on country populations (Petrie, 2013b). Notwithstanding the fact that public sector expenditure on health and welfare had not caused the economic recession in the U.K., "austerity" politics have ensured the reduction of state spending above all other considerations. The policies and legislation of the Coalition government have reduced the level and comprehensive nature of the welfare benefits system and imposed major cuts to local authority budgets.

Since the 1980s public sector provision affecting children has been systematically reduced by transforming the Welfare State into a framework of welfare markets initiated by an explicit political agenda (Scott-Samuel et al., 2014). In part this has been due to a shift in political ideologies regarding the balance between the state and parents' responsibilities for child welfare. The main thrust, however, has been neo-liberal economic ideology. The evidence shows that the consequences for many children have been disastrous as the role of local authorities has been limited to commissioning rather than providing children's services and private sector enterprises have increased their market share:

the way out-sourcing has been done in the last couple of decades has created a major problem. It has left the Government buying services in a market and using contracts

\footnotetext{
${ }^{3}$ Blair governments: 1997-2001; 2001-2005; 2005-2007.
} 
that are far too heavily weighted in favour of the companies they are buying from, and their shareholders. (Williams, 2012, p. 4)

Stability and consistency in relationships are essential for any human being, especially children, at times of change and trauma. Yet the demise of what has been termed the "helping relationship" in human services has become evident as markets in health, welfare, and education have grown (Petrie, 2013a). Children have become commodities in transactions between the state and providers as the contractual implications of cost and revenue supersede any individual needs for continuity and stability a child may have. The move from the Welfare State to welfare markets and the dominant role of the "for-profit" sector in service provision has commodified children in contractual exchanges and can be seen when child protection services and children's day care are examined.

\section{Protecting Children}

Harm for children has to be understood as a spectrum. At one end of the spectrum are extreme and prolonged harms, often leading to death, that are indicative of a total depersonalisation of a child and these are fortunately rare. At the other end of the spectrum serious harms can be caused to a child as a result of situational stressors - harms that are unlikely to reoccur if the stressors are removed. In fact in the U.K. child deaths from adult abuse have remained remarkably static for the last 30 years. While annual statistics fluctuate a little, the longer-term pattern has been fairly stable at 100 to 150 child deaths per year from cruelty (National Society for the Prevention of Cruelty to Children [NSPCC], 2001; Laming, 2009).

Nevertheless, during the last three decades there have been a series of public inquiries into shocking child deaths from abuse. Learning gained from inquiries and research in the 1970s and 1980s led in part to the Children Act 1989 that overhauled and consolidated all legislation for children apart from adoption. One intention of the CA 1989 was to ensure that child protection services were not solely concerned with the detection or prevention of immediate harms to children. As noted earlier, being assessed as a "child-in-need" under section 17 of the Act is the legal passport to state provided or purchased services and places a statutory duty on local authorities to provide a range of community-based services in order to safeguard the welfare of children. Statutory child protection services provided by the state operate within the purchaser/provider split of welfare markets; child protection workers are primarily concerned with assessing whether or not abuse has occurred and determining if the state should intervene to remove a child from their family. If removal is not appropriate, support may be given in the community to prevent abuse.

For children in the community living with their families, the legal concept of a "childin-need" already became a rationing device by the late 1990s. If a child did not meet the formalised criteria of being a "child-in-need", including a need to be protected from abuse, they did not receive services, either purchased or provided for by the local authority. The contractual framework inevitably made cost the primary consideration for local authorities and the denial of services was a key factor in several appalling child deaths from abuse at the beginning of the new millennium, notably that of the seven-year-old immigrant child Victoria Climbié (Johnson \& Petrie, 2004). The Laming Inquiry into Victoria's death criticised local authorities for using the "child-in-need" assessment process as a rationing mechanism: 
The use of eligibility criteria to restrict access to services is not found in either legislation or in guidance and its ill-founded application is not something I support. Only after a child and his or her home circumstances have been assessed can such criteria be justified in determining the suitability of a referral, the degree of risk, and the urgency of the response. (Laming Report, 2003, p. 13)

Even if the state has intervened to remove a child, however, the operation of the market determines that other workers take responsibility for purchasing and monitoring outof-family placements. Although the involvement of the "for-profit" sector was minimal at the end of the 1990s, the sector is now the major provider of residential and foster placements (Williams, 2012). Placing children in care settings and the involvement of other social work/ social care personnel often means a child will experience many key workers during their care history. The operation of the market mechanism in child protection, despite the best efforts of committed workers, commodifies children as services are designed to conform to the purchaser/provider model and organisational requirements. Short-termism is endemic leading to a lack of consistency and stability for children in care as they are moved from their home area, often moving placement many times, in order to deliver, "profit, in vast amounts, into the hands of those whose primary interest is profit” (Williams, 2012, p. 31). A child's optimal development and safety requires an individualised response to their individual needs that is consistent over time but, as evidence shows, market mechanisms mean that stable, long-term helping relationships are difficult to achieve.

Local authorities are currently struggling to meet even minimal statutory child protection duties and the latest report from the National Society for the Protection of Children (NSPCC) states that child protection systems are "buckling under pressure" (Jutta, Bentley, Miller, \& Jetha, 2014, p. 4) because budget levels for local authorities in the U.K. in 2012/13 were approximately the same as they were in 2006/7 despite the increase in referrals and concerns. A recent survey of 600 social workers and managers revealed that more than $80 \%$ said that the thresholds for intervention have risen since 2012/13 as a result of budget cuts in their area (Pemberton, 2013). The response in April 2014 by the Department of Education to child protection services in crisis was to propose privatisation. In June 2014, due to concerted resistance from professionals, academics, and charities, these proposals were abandoned and profit-making organisations will now be barred from core child protection work.

Worryingly, there are now very few services in the community for children living with their families in order to safeguard their welfare and avoid statutory intervention. The impact of public sector cuts as a consequence of "austerity" policies has meant that many local authorities in the U.K., particularly in the impoverished North and Midlands, have ceased funding discretionary services and are attempting to meet statutory responsibilities with rising poverty and diminishing resources (Hastings et al., 2013). For example, Liverpool has to cut $£ 156 m$ ( $\$ 281 \mathrm{~m} \sim \mathrm{CAN}$ ) from its budget over three years. The local authority plans to axe 300 jobs, reduce adult services by $£ 46 \mathrm{~m}(\$ 83 \mathrm{~m} \sim \mathrm{CAN})$, children’s services by $£ 16 \mathrm{~m}$ ( $\$ 28 \mathrm{~m} \sim \mathrm{CAN}$ ) and increase council tax by 1.99\% (British Broadcasting Corporation [BBC], 2014). Voluntary and community sectors are also suffering cuts as public sector budgets have been slashed. The National Council of Voluntary Organisations (NCVO) projects that public funding for the sector could be $£ 1.7$ billion lower in 2017/18 than it was in 2010/11 and could even be as much as $£ 2.1$ billion if the public sector cuts are passed on disproportionately, as has happened to date (NCVO, 2013). It is not surprising that the NSPCC has identified a rise in harms to children caused by neglect: 
Neglect is much more prevalent in serious case reviews than had previously been understood (we found neglect in 60 per cent of the 139 reviews from 2009-2011). (Brandon, Bailey, Belderson, \& Larsson, 2013, p. 7)

This same period, of course, coincided with the economic crisis affecting the U.K. and indeed the correlation between child poverty and child welfare is well understood. The financial and housing circumstances of many families with children have steadily deteriorated since the recession began, and it is not surprising that the rise in child poverty and food bank applications correlates with the rise in assessments of child neglect (NCB, 2013; Cooper \& Dumpleton, 2013).

The collective approach to safeguarding the welfare of all children in the United Kingdom enshrined in the Welfare State has been eroded and child protection services in a market economy failed to protect some children from abuse and death because the rationing mechanisms deployed excluded them from contracted services. Child protection services are now struggling to meet the most basic of statutory duties, let alone support children in the community through long-term, stable, and consistent helping relationships. Children's day care is also distributed through flawed market mechanisms but with different systemic failings. Cost, availability, and accessibility have become increasingly problematic as day care for children is now primarily a service to facilitate parental employment rather a service for children's development.

\section{Children's Day Care}

Policies and legislation initiated by New Labour and progressed by the current Coalition government rest on the assumption that fewer children live in poverty if their parents are employed. In addition, changes to fiscal benefits have ushered in a new system of compulsion and sanctions, and have meant that the demand for children's day care has increased. In this policy context children are simply barriers to parental employment and have to be placed in whatever provision is available so parents can enter the labour market and avoid benefit sanctions. Although current regulations are supposed to protect lone parents from sanctions if they can't find day care or need to work school hours, these regulations are confusing and poorly understood (Finn \& Casebourne, 2012).

Children's day care has always been provided by a mixed economy and traditionally the main providers have been childminders who are mainly women working in their own homes. The involvement of the larger scale and franchised "for-profit" sector in this service area, however, has increased alongside the demand generated by welfare reform, increased under-employment, and low wages. The most recent government survey (Brind et al., 2014) reveals that $61 \%$ of full-time group day care is provided by the "for-profit" sector and about $30 \%$ by the third sector. Holiday care is also mainly offered by the "for-profit" sector. Although childminders remain significant providers, the average numbers of hours they offer per week are only 16 in term-time and 22 in school holidays. They are also least likely to work in areas defined as "deprived". Schools offer some part-time preschool places during term-time. Consequently under half of all local authorities in 2014 had stimulated enough day care for working parents with big differences between local authorities. By November 2013, less than $60 \%$ of eligible two-year-olds had been allocated their free part-time nursery place in 37 local authorities. Of these spaces, 25 were in London with suitable care for 12- to 14year-olds being hardest to find (Rutter \& Lugton, 2014). There is evidence that less than $50 \%$ of all local authorities have sufficient day care for the under 2s, 5- to 14-year-olds, and 
disabled children (Day Care Trust/ Family and Parenting Institute, 2013). As a result of the market economy of day care, therefore, the cost/revenue implications for providers have meant that children with additional needs, who are older or who live in certain areas, are less likely to access provision.

Parents who are sufficiently affluent can purchase individualised care at home from nannies or pay premium prices for specialised programmes for older children, whilst parents with low income face extra difficulties. Employers are reluctant to offer hours that fit school timetables, term times or additional closures, let alone offer workplace flexibility to respond to a child's illness or other need, and it's especially difficult for those working at weekends or evenings. It has been estimated to cost the U.K. economy nearly $£ 100 \mathrm{~m}$ in lost working days as parents take sick leave to care for their children and $12 \%$ of those surveyed had given up employment entirely because of difficulties in finding suitable provision (Rutter \& Lugton, 2014).

Examples from a small qualitative study undertaken with lone mothers in Liverpool (Ahmad, Lance Jones, Petrie, \& Reith, 2010) reveal how parents struggle to meet the needs of their children when policies define them primarily as barriers to employment:

This day I couldn't get no one to mind them ... I rang up work and she said unless you come in we're going to sack you and I thought "right better go in" so I said to my eldest, who was twelve, “don't touch anything”, I did all their butties and everything and I went to work... all day I was nearly sick thinking they could set the house on fire or anything so I walked out of work, went to the Jobcentre and went to the Adviser and said "listen, I've left the job, I've left my kids in danger, they could set the house on fire or anything because I've gone out to work and .. I don't care you can stop my money”. (C2, p. 30)

It is especially hard for parents when children don't want to go to the only service on offer:

After school club ... The kids didn't want to go to that. They were unhappy, which made me unhappy and I wasn't happy going to work, because they were unhappy. (B7, p. 13)

Parents are clear that children's needs are overlooked in the fiscal benefits system now in place:

Are you assessing the needs of the child in all this - it seems to have been forgotten along the way, being at home with a child is so discredited, the whole system conspires against single parents. (A6, p. 10)

Even when parents have sufficient income to negotiate the market and find suitable placements, they pay substantially more than their EU counterparts for day care. For example, sending a two-year-old to nursery for 25 hours a week costs £109.89 (\$201.87 CAN) whilst the Office of National Statistics shows that the average weekly expenditure for food is $£ 56.80$ (\$104.34 CAN) and transport £64.10 (\$117.75 CAN) (Rutter \& Stocker, 2014). Most parents buying full-time day care contribute $20 \%$ to $30 \%$ of their gross income and since 2009, day care costs have risen 27\% (Rutter \& Stocker, 2014). Notwithstanding regulation by the state, children's day care is primarily subject to market forces that have 
spiralled costs for those lucky enough to find provision: A nursery place now costs $77 \%$ more in real terms than it did in 2003, whilst earnings have stayed still (Rutter, 2013).

So although day care of all kinds (including after-school and holiday care for older children) is primarily perceived as a service for parents to enable them to enter the workforce and escape poverty, the cost of placing their children in the limited provision available impoverishes many working households and may not meet the needs of their children. The new regime of benefit sanctions for parents who leave or refuse paid employment and the lack of choice of provision clearly shows that children, in policy terms, are viewed primarily as parental belongings to be placed in whatever provision is available or left home alone if there is no provision.

\section{From the Welfare State to Welfare Markets: Commodifying Children}

The first part of this paper outlined the approach to the welfare of children enshrined in the post-WWII Welfare State in the U.K. The underpinning principle of universal benefits of right led to a high level of collective responsibility for all of the nation's children who were constructed in policy terms as future social capital. From the 1980s, a sea change took place with policies and legislation enacted by successive governments in order to establish a market economy in welfare. In part this was due to moral concerns about state intervention in family life and stimulated a rebalancing of responsibilities between the state and parents for the well-being of children. Another major stimulus, however, was the increasing dominance of neo-liberal economic ideas. Replacing universal state provision with a market economy in welfare was promoted as the most effective way to safeguard scarce state resources and ensure those who really needed services received them. State provision became residual and the primary role of local authorities became one of commissioning and regulating with their expenditure monitored by government through performance indicator targets. I have argued above in relation to child protection and day care services that one consequence of markets in welfare has been to objectify and commodify children. For services to be contracted within a given timescale "needs" have been codified in assessment templates in order to be quantified and costed turning children into cost/revenue commodities. Since the 1990 s as a result of outsourcing, the "for-profit" sector has become a major provider of services for children such as residential care, foster care, and group day care, with state provision under pressure such as child protection services being threatened with privatisation by government. Although there is as yet no comprehensive data there are strong indications that outsourcing is costly and the standards of some contracted services are poor (Williams, 2012).

Evidence now indicates that the situation has worsened for large numbers of children excluded from welfare markets altogether as a result of the U.K. government's "austerity" policy responses to the global recession including large-scale public sector cuts. Statistics show that parental employment does not protect children from poverty. The government's Social Mobility and Child Poverty Commission have revealed an enormous rise in poverty among working families. By 2011/2012 twice as many children lived in poverty in working households than in workless households. Furthermore, income levels rather than hours of work are the best predictor of child poverty as full-time work is not a sufficient guarantee of evading poverty (Gregg, 2014). Although since 2011 the overall number of people in employment has been going up this has masked the problem of underemployment. More people wishing to work full time are working part time, sometimes with several part-time jobs, or are on "zero hours" contracts as this is the only employment available (Bell \& Blanchflower, 2013). 
Refusal of service by a local authority despite evidence of "need" has recently been legitimised. The legal definition of "child-in-need" (section 17, CA 1989, the passport to state provided or purchased services) does not offer clear operational guidelines and is dependent on legal precedent. Laming's (2003) liberal interpretation of “a child-in-need” in the Climbié Inquiry has been firmly rejected in 2014. The latest judgement (MN and KN v London Borough of Hackney) confirms that "in need" does not mean children who are objectively in need as decided by a court but children whom the local authority has assessed as being "in need" (Campbell 2013). Clearly at a time of severe public sector cuts this decision will inevitably exclude many from services and already the health and well-being of children invisible in the market economy are being severely compromised as emerging evidence shows.

\section{The State of the Nation's Children: Beyond Markets}

The rise in the unequal distribution of income and wealth in the United Kingdom since the 1980s has led to an unprecedented increase in child poverty (NCB, 2013). It has been estimated that by 2015 almost 7 million of the nation's 13 million youngsters will be living in homes with incomes judged to be less than the minimum necessary for a decent standard of living and 90\% of families will be worse off in 2015 than 2010 (Reed, 2013). The distribution of wealth is highly unequal, with the top $10 \%$ owning 100 times more than the bottom $10 \%$. Moreover, those families most likely to be disadvantaged are of Black African or Bangladeshi ethnic identity, lone parents (mostly women), and Muslims (Rowlingson, 2012). The health of poor children is now being dramatically undermined by food poverty and inadequate housing.

Despite the U.K. being one of the richest nations in the world, there has been a huge increase in applications to food banks by families with children (Aldridge \& McInnes, 2014; Duffy, 2014; Cooper \& Dumpleton, 2013). Food banks are not provided through welfare market contracts but by the informal sectors, including church and voluntary organisations. The most common reasons for applications to food banks are as a result of incorrect, delayed, or reduced benefit payments or benefit sanctions (Cooper \& Dumpleton, 2013). The unemployed are now defined in legislation and policies as requiring coercion through sanctions including reduction or removal of benefit whether or not they care for children; although, the government's own evaluation of the new benefit system suggests major operational flaws (Oakley, 2014).

Public health experts (Taylor-Robinson et al., 2013; Ashton et al., 2014) have raised many concerns about food poverty. In particular, the number of malnutrition-related admissions to hospital has doubled since 2008-09. Figures from the Institute for Fiscal Studies also indicate a decrease in calories purchased and substitution with unhealthier foods, especially in families with young children. Alongside the well-documented rise in food bank referrals, this leads them to argue this is:

a public health emergency that could go unrecognised until it is too late to take preventive action .... Access to an adequate food supply is the most basic of human needs and rights. We should not allow food poverty in the UK to be the next public health emergency. (Taylor-Robinson et al., 2013, p. 1) 
Those who have recourse to food banks also rely on cheap food and cheap food is often contaminated food. The Food Standards Agency (2014) has found that 59\% of supermarket chickens carry Campylobacter, the commonest cause of food poisoning in the U.K. that is particularly dangerous to the very young, the elderly, and those with additional ill-health. However the primary consequence of poor diet in contemporary times in affluent societies is obesity and childhood obesity is of special concern. Evidence shows that the prevalence of obesity in children is closely related to deprivation (National Obesity Observatory [NOO], 2013) as cheap food is nutritionally inadequate whether it is "junk" or "convenience" food. In either case, commercial sector food producers target poorer families, and children in particular, through low-cost products, advertising, and incentives (Campbell, 2014).

There are other indicators of concern regarding the nation's children. Although infant, child, and adolescent mortality has declined substantially and continues to decline, rates are significantly higher than in many other European countries and there are marked inequalities in death rates across the U.K. (Wolfe, Macfarlane, Donkin, Marmot, \& Viner, 2014). Children in the U.K. are more likely to die before they reach their 5th birthday than any other Western European country except Malta (Wang et al., 2014). The U.K. rate of 4.9 per thousand is double that of Iceland, the best in Europe, where rates are only 2.4 per thousand. Poverty and deprivation together with cuts in welfare are directly linked to deaths of younger children (Wolfe et al., 2014) and rates of suicide amongst young people have not declined and remained high (Wolfe et al., 2014). There is some evidence to suggest that child murder by parents who then attempt suicide also rises at times of economic downturn (Walklate \& Petrie, 2013).

Poor health is also caused by inadequate housing. In the U.K. housing has been a recognised public health issue since the mid-19th century. Since the 1980s there has been a diminution in state-provided housing and a rise in home ownership as a result of the housing policies of successive governments. Now the consequences of the global recession that began in 2007/08 and subsequent "austerity" policies have had a disastrous impact on the housing conditions of many people in the U.K. Redundancies, the casualisation of labour, and low wages have exposed many homeowners to personal financial catastrophe and mortgage repossessions. For those in rented accommodation there is substantial evidence from reviews by the United Nations and even the Department for Work and Pensions that the so-called “Bedroom Tax” has exacerbated - and not alleviated - housing problems (Rolnik, 2013; Department for Work and Pensions, 2014). From the first of April 2013, if a tenant is assessed by their local authority as having one or more spare bedrooms (two children aged 10 years or under regardless of gender are now expected to share a room) housing benefit is no longer granted for the full rent. Reductions in housing benefit are quite substantial and average $£ 14$ per week ( $\$ 25.70 \sim$ CAD) for one bedroom and $£ 25$ per week (\$46 CAD) for two. Families have to choose between reducing their income substantially by remaining in housing and a locality familiar to them, or moving into accommodation that is often substandard and sufficiently far away from their old neighbourhood that children have to move school.

In 2013, women in an urban area in Liverpool spoke with passion about how the "Bedroom Tax" was destroying their community. For example, a key local figure was a mother, grandmother, and great-grandmother with many family members living locally. They said "her house is never empty" yet she has been assessed as having two spare bedrooms and 
unless she pays an additional $£ 25$ a week will have to move. There are no smaller properties in the area. They said:

What politicians don't understand about Liverpool is intergenerational support between the community. Move a grandmother out and who will pick up the kids? Families support one another. Strip them of their pride, take everybody's dignity and pride from them - it's a slow tortured death. (personal communication, June 19, 2013)

There are increasing numbers of three- and four-bedroomed properties that are now hard to let and, together with the rising costs of private sector rents, have led to greater numbers of families living in substandard, overcrowded accommodation.

In addition to the consequences of poverty some children are excluded from services because their identity has made them targets of specific policies and legislation. Politicians respond to the dominant discourse in the U.K. that places blame for diminished state services on the influx of immigrants rather than the unethical and in some cases criminal behaviour of banks and financial enterprises that caused the global financial crisis and triggered "austerity" policies (Gowan, 2009). During the second reading of the recent Immigration Bill in the House of Lords it emerged that the definition of "child" was linked to birthplace and length of residency in order to exclude many children. Lord Roberts of Llandudno raised one of many concerns:

I also suggest that this House must review the Bill's current definition of who counts as an asylum-seeking child. A number of clauses seek to limit the definition to those who are British-born or who have been here for seven years or more. Worryingly, this excludes most asylum-seeking children, many of whom come here as teenagers. (House of Lords Debate, 2014)

It has been shown, however, that immigrants from the European Economic Community (EEC) between 1995 and 2011 contributed 4\% more into the fiscal economy than they received (Dustmann \& Frattini, 2013). Between 2001 and 2011 immigrants from outside the EEC paid into the system $2 \%$ more than they took out, which is astonishing when considering the United Kingdom was running an overall budget deficit during this period. The authors conclude:

Our analysis thus suggests that - rather than being a drain on the UK's fiscal system immigrants arriving since the early 2000s have made substantial net contributions to its public finances, a reality that contrasts starkly with the view often maintained in public debate. (p. 27)

Nevertheless immigrants and their children remain particularly singled out for exclusion as is evident in the limitations to accessing free health care now the Immigration Act 2014 is law. Furthermore, despite promises made in 2010 by the Coalition government to end the much criticised treatment of child asylum seekers, conditions for them at Heathrow Airport remain appalling. Inhumane arrangements are made for their deportation including deporting those reaching 18 years before their education is completed (Independent Monitoring Board [IMB], 2013; Matthews, 2014).

Other children are making up for the shortfall in market provision by undertaking caring duties for family adults. There is a well-researched correlation between low financial 
resilience among citizens - in other words debt and poverty - and ill health. This includes mental ill health as well as suicide and addictions, and physical ill health including obesity, malnutrition, and diseases associated with poor nutrition (Wilkinson \& Pickett, 2009; Stuckler, Basu, Suhrcke, Coutts, \& McKee, 2009; Dorling, 2011; Stuckler \& Basu, 2013). In effect the greater the gap between the affluent members of a society and the poor, the greater the incidence of ill health. These consequences not only affect the health of adults but place caring duties on children too. The Office of National Statistics (ONS) data released in 2013 (Hounsell, 2013) reveal that nearly a quarter of a million children aged 18 years or under in England and Wales are caring for a relative and this has increased by one-fifth since 2001. About 23,000 young carers are under nine years. Young carers are more likely to live in lowincome families, miss school, underachieve educationally, and have a long-term illness, disability, or special educational need than their peers. The burden carried by these children is in sharp contrast to the intended principles of the National Health Service, established when the economic circumstances of the U.K. at the end of World War II were even more precarious than at present. In a statement to the House of Commons on the $9^{\text {th }}$ February 1948, Aneurin Bevan, Secretary of State for Health said:

We ought to take pride in the fact that, despite our financial and economic anxieties, we are still able to do the most civilised thing in the world - put the welfare of the sick in front of every other consideration. (House of Commons Debate, 1948)

Other children become invisible because their behaviour has led to their ejection from services, as they are perceived solely in deficit terms. Over 10,000 children and young people a year run away from care and many remain unprotected and exploited (All Party Parliamentary Group [APPG], 2012). It is estimated that $65 \%$ of residential homes for children and two of the three biggest foster placement providers are now run by the private sector (Williams, 2012). Third sector organisations have largely withdrawn from competitive bidding for state contracts for services for troubled children as awards are granted to those providers whose costs are insufficient to provide a quality service. Charities initially supported services through additional funds generated by charitable giving, but this has not proved sustainable in the long run (Williams, 2012). Despite the belief that reducing state provision and introducing "free market" principles into the public sector would deliver services that were "Economic, Efficient and Effective" (Burden et al., 2000, p. 52), provision by the private sector has not reduced state expenditure. An average of $£ 200,000(\$ 361,579$ CAN) per child in care, per year, is spent on residential placements yet these children are three times more likely to run away than other children (APPG, 2012). The recent scandals of child sexual exploitation in Rochdale highlight how easy it is for these runaways to continue to be treated as commodities, although this time in sex not welfare markets (RBSCB, 2013). The RBSCB inquiry report (2013) highlights how children were discussed in deficit terms by all agencies involved:

There are repeated comments made to and about the young people based on a view that it was within their power to "keep themselves safe". A similar frequently made comment was in relation to the young people "engaging in risky behaviour", suggesting that this was something they could chose not to do. (p. 70, 4.4.59)

Despite the fact these children were in and out of residential care and other services, ultimately they were deemed to be the architects of their own difficulties and outside any contractual obligation. 


\section{Conclusions}

The dismemberment of the Welfare State began during the Thatcher governments and has continued apace under every government since then. This has meant the underpinning foundation of policies and legislation has moved away from the principle of universal benefits of right to market mechanisms designed to target those considered most deserving and sanction those judged socially irresponsible. The increased emphasis on targeting those most "in need", welfare markets, contracts rather than grant aid for the voluntary and not-for-profit sectors, and increasing numbers of state contracts awarded to the "for-profit" sector has ensured children have acquired a use-value in commercial exchanges - in other words they have been commodified. The combination of welfare markets and public sector cuts, however, have created conditions whereby some children are no longer commodities with cost/revenue implications for the state and service providers, but in some instances are deemed to have no value at all.

Welfare markets have failed children. The recent report by the National Children's Bureau (2013) compares findings to its first report in 1969 and concludes that the situation today for children is no better than 50 years ago and is, in some respects, much worse. In particular, child poverty has increased by 1.5 million and children living in deprived areas are much more likely to be obese, suffer accidental injuries, and have less access to green space and play. The economic crisis that engulfed Britain was not caused by public sector expenditure; nevertheless it is the public sector that has had to bear the cost with dire consequences for many children. Stuckler and Basu (2013) conclude that "austerity” policies are not only harmful to the health of the citizens, but that the policies themselves are founded on ideology not economic evidence. Nevertheless, "the greatest tragedy of 'austerity' is not that it has hurt our economies ... [but] is the unnecessary human suffering that 'austerity' has caused” (p. 141).

There is a further dimension to the socio-political characteristics of the U.K. that is likely to fundamentally affect the dominance of neo-liberal economics and welfare markets in the future resulting from the devolution of Scotland, Wales, and Northern Ireland. The Scottish Parliament, Welsh and Northern Ireland Assemblies were established in 1999 in order to devolve some powers and decentralise government. Although the main fiscal powers' relation to welfare benefits has been retained by national government, many responsibilities concerning health and welfare have been devolved to the three countries. Since 1999 it has become apparent that the social policies of these countries especially towards children, and notwithstanding their limited economic resources, are very different to those in England. For example in Wales, public sector developments have been influenced by the Beecham Report (2006) that signalled an intent to move away from markets in public sector services on the grounds of principle and practicality toward a "citizen model" (Beecham Report 2006, p. 5). Scotland has abolished university tuition fees and prescription charges and although the recent referendum did not allow the country to achieve full independence from the U.K., the Scottish Parliament remains determined to offer an alternative to "austerity” policies and invest in public spending (Scottish Government, 2014). Indeed, political agreement has now been reached between all parties that Scotland will acquire greater control over tax and revenue expenditure. 
International Journal of Child, Youth and Family Studies (2015) 6(2): 275-294

Whether the current differences in policy direction between the countries forming the U.K. will begin to converge or continue to widen will be critical as the scale and depth of divisions between citizens, localities, and political representatives, in a nation as small as the United Kingdom, are major causes for concern for the future of our children. Children are the first to bear the brunt of whatever socio-political and economic systems are in place but have no influence, either as voters or as part of lobby or pressure groups, over decisions that affect their lives. Children have not only become individualised commodities in welfare markets but have also become the collateral damage of the "austerity" economy in the U.K. 
International Journal of Child, Youth and Family Studies (2015) 6(2): 275-294

\section{References}

Ahmad, S. B., Lance Jones, G., Petrie, S., \& Reith, L. (2010). Are we nearly there yet? Managing children and work. Liverpool: University of Liverpool.

Aldridge, H., \& McInnes, T. (2014). Multiple cuts for the poorest families. Oxford: New Policy Institute/ Oxfam Research Report.

All Party Parliamentary Group (APPG). (2012). Report from the joint inquiry into children who go missing from care. London: House of Commons.

Ashton, J., Middleton, J., \& Lang, T., on behalf of 179 signatories. (2014). Open letter to Prime Minister David Cameron on food poverty in the U.K. The Lancet, 383(9929), 631. http://dx.doi.org/10.1016/s0140-6736(14)60536-5

Baird, P. A. (1996). Ethical issues of fertility and reproduction. Annual Review of Medicine, 47, 107-116. http://dx.doi.org/10.1146/annurev.med.47.1.107

British Broadcasting Corporation (BBC). (2014, March 6). Liverpool City Council approves $£ 156 \mathrm{~m}$ budget cuts. BBC News. Retrieved from http://www.bbc.com/news/ukengland-merseyside-26462628.

Beecham Report. (2006). Beyond boundaries. Citizen-centred local services for Wales. Cardiff: Beecham Review Secretariat.

Bell, D., \& Blanchflower, D. (2013, May). Underemployment in the UK revisited. National Institute Economic Review, 224, 8-22. http://dx.doi.org/10.1177/002795011322400110

Beveridge, W. (1942). Social insurance and allied services. London: HMSO.

Brandon, M., Bailey, S., Belderson, P., \& Larsson, B. (2013). Neglect and serious case reviews. London: NSPCC/University of East Anglia.

Brind, R., McGinigal, S., Lewis, J., Ghezelayagh, S., Ransom, H., Robson, J., Street, C. \& Renton, Z. (2014). Childcare and early years providers survey 2013. London: Department for Education.

Burden, T., Cooper, C., \& Petrie, S. (2000). Modernising social policy. Unravelling New Labour's welfare reforms. Aldershot: Ashgate.

Campbell, A. (2013). "Let's be frank”: The decision in MN and KN v London Borough of Hackney. London: Hardwicke Barristers. Retrieved from http://www.hardwicke.co.uk/insights/articles/lets-be-frank-the-decision-in-mn-andkn-v-london-borough-of-hackney

Campbell, D. (2014, March 3). Children are being 'bombarded' by junk food ads, research has found. The Guardian. Retrieved from http://www.theguardian.com/society/2014/mar/21/children-bombarded-junk-food-ads 
International Journal of Child, Youth and Family Studies (2015) 6(2): 275-294

Cooper, N., \& Dumpleton, S. (2013). Walking the breadline. The scandal of food poverty in $21^{\text {st }}$ century Britain. Manchester: Church Action on Poverty/Oxfam.

Day Care Trust / Family and Parenting Institute. (2013). Childcare costs survey 2013. London: Day Care Trust.

Department for Work and Pensions / Social Science in Government. (2014). Evaluation of removal of the spare room subsidy. Interim report. London: Author.

Dorling, D. (2011). Injustice: Why social inequality persists. Bristol: The Policy Press.

Duffy, S. (2014). Counting the cuts. Sheffield: Centre for Welfare Reform.

Dustmann, C., \& Frattini, T. (2013). The fiscal effects of immigration to the UK. Discussion Paper, CDP No 22/13. London: Centre for Research and Analysis of Migration, University College.

Finn, D., \& Casebourne, J. (2012). Lone parent sanctions: A review of international evidence. London: Centre for Economic and Social Inclusion.

Food Standards Agency. (2014). Campylobactor survey results. Edinburgh: Food Standards Agency. Retrieved from http://www.food.gov.uk/newsupdates/news/2014/9279/campylobacter-survey

Friedman, M. (1962). Capitalism and freedom. Chicago: University of Chicago Press.

Glass, N. (1999). Sure Start: The development of an early intervention programme for young children in the United Kingdom. Children and Society, 13(4), 257-264. http://dx.doi.org/10.1002/chi569

Gowan, P. (2009). Crisis in the heartland. Consequences of the new Wall Street system. New Left Review, 55(Jan.-Feb.), 5-29.

Gregg, P. (2014, March 18). Working Poverty: What's going on? Social Mobility and Child Poverty Commission Blog. Retrieved from https://smcpcommission.blog.gov.uk/2014/03/18/working-poverty-whats-going-on/.

Hastings, A., Bailey, N., Besemer, K., Bramley, G., Gannon, M., \& Watkins, D. (2013). Coping with cuts? Local government and poorer communities. Programme paper, austerity. York: Joseph Rowntree Foundation.

Hounsell, D. (2013). Hidden from view: The experiences of young carers in England. London: The Children's Society.

House of Commons (HC) Debate. (1948). National Health Service, 09 February 1948. Hansard, 447, cc35-160.

House of Lords (HL) Debate. (2014). Immigration Bill, second reading. Hansard, 752, 480. 
International Journal of Child, Youth and Family Studies (2015) 6(2): 275-294

Independent Monitoring Board. (2013). Report on the non-residential short-term holding facilities at London Heathrow Airport for the year February 2012 to January 2013, London: IMB Secretariat.

Johnson, S., \& Petrie, S. (2004). Child protection and risk-management: The death of Victoria Climbié. Journal of Social Policy, 33(2), 179-202. http://dx.doi.org/10.1017/s0047279403007487

Jutta, S., Bentley, H., Miller, P., \& Jetha, N. (2014). How safe are our children? London: NSPCC.

Laming, Lord (2009). The protection of children in England: A Progress Report. London: TSO.

Laming Report. (2003). The Victoria Climbié Inquiry: Report of an inquiry by Lord Laming (Command 5730). London: The Stationery Office.

Matthews, A. (2014). What's going to happen tomorrow? Unaccompanied children refused asylum. London: Office of the Children's Commissioner.

National Children's Bureau (NCB). (2013). Greater expectations: Raising aspirations for our children. London: Author.

National Council of Voluntary Organisations. (2013). Counting the cuts: The impact of spending cuts on the UK voluntary and community sector. 2013 update. London: Author.

National Obesity Observatory (NOO). (2013). Child obesity and socio-economic status. London: Public Health England.

National Society for the Prevention of Cruelty to Children (NSPCC). (2001). Out of sight. NSPCC report on child deaths from abuse 1973-2000 (2nd edition). London: Author.

Oakley, M. (2014). Independent review of the operation of Jobseeker's Allowance Sanctions validated by the Jobseeker's Act 2013. London: Department for Work and Pensions.

Pemberton, C. (2013, November 19). Community care survey shows how rising thresholds are leaving children in danger. Community Care. Retrieved from http://www.communitycare.co.uk/2013/11/19/community-care-survey-exposes-risingthresholds-leaving-children-danger/

Petrie, S. (2010). The 'commodification' of 'children in need' in welfare markets: Implications for managers. Social Work and Social Sciences Review, 14(1), 9-26. http://dx.doi.org/10.1921/095352210x495104

Petrie, S. (2013a). From 'commodification' to collateral damage: 'children-in-need' and austerity policies. In J. Lawler \& P. Hafford-Letchfield (Eds.), Leadership and management in social work (pp. 13-38). London: Whiting \& Birch.

Petrie, S. (Ed.). (2013b). Controversies in policy research. Critical analysis for a new era of austerity and privation. Basingstoke: Palgrave Macmillan. 
International Journal of Child, Youth and Family Studies (2015) 6(2): 275-294

Petrie, S., \& Wilson, K. (1999). Towards the disintegration of child welfare services. Social Policy and Administration, 33(2), 181-196. http://dx.doi.org/10.1111/1467-9515.00142

Rochdale Borough Safeguarding Children's Board (RBSCB). (2013). The overview report of the serious case review in respect of young people 1,2,3,4,5 and 6. Rochdale: RBSCB.

Reed, H. (2013). A bleak future for families. London: Landman Economics /TUC.

Rolnik, R. (2013). Report of the Special Rapporteur on adequate housing as a component of the right to an adequate standard of living and on the right to non-discrimination in this context. Mission to the United Kingdom of Great Britain and Northern Ireland. December 2013. New York: United Nations.

Rowlingson, K. (2012). Wealth inequality: Key facts. Birmingham: Policy Commission on the Distribution of Wealth, Birmingham University.

Rutter, J. (2013). Childcare costs survey 2013. London: Family and Childcare Trust.

Rutter, J., \& Lugton, D. (2014). Holiday childcare survey 2014. London: Family and Childcare Trust.

Rutter, J., \& Stocker, K. (2014). Childcare costs survey 2014. London: Family and Childcare Trust.

Scott-Samuel, A., Bambra, C., Collins, C., Hunter, D., McCartney, G., \& Smith, K. (2014). The impact of Thatcherism on health and well-being in Britain. International Journal of Health Services, 44(1), 53-71. http://dx.doi.org/10.2190/hs.44.1.d

Scottish Government. (2014). Scotland's referendum. Edinburgh: Scottish Government. Retrieved from: https://www.scotreferendum.com/

Shuster, E. (2003). Human cloning: Category, dignity, and the role of bioethics. Bioethics, 17(5-6), 517-525. http://dx.doi.org/10.1111/1467-8519.00365

Spar, D. L. (2006). The baby business: How money, science and politics drive the commerce of conception. Boston: Harvard Business School Publishing.

Stuckler, D., Basu, S., Suhrcke, M., Coutts, A., \& McKee, M. (2009). The public health effect of economic crises and alternative policy responses in Europe: An empirical analysis. The Lancet, 374(9886), 315-323. http://dx.doi.org/10.1016/s0140-6736(09)61124-7

Stuckler, D., \& Basu, S. (2013). The body economic: Why austerity kills. London: Allen Lanep.

Taylor-Robinson, D., Rougeaux, E., Harrison, D., Whitehead, M., Barr, B., \& Pearce, A. (2013). The rise of food poverty in the UK. British Medical Journal, 347, f7157. doi: 10.1136/bmj.f7157 
The Telegraph. (2014, August 1). Legal situation of surrogacy explained. Retrieved from http://www.telegraph.co.uk/news/worldnews/asia/thailand/11006524/Legal-situationof-surrogacy-explained.html

Walklate, S., \& Petrie, S. (2013). Witnessing the pain of suffering: Exploring the relationship between media representations, public understandings and policy responses to filicide-suicide. Crime, Media, Culture, 9(3), 265-279. http://dx.doi.org/10.1177/1741659013493917

Wang, H., Liddell, C. A., Coates, M. M., Mooney, M. D., Levitz, C. E., Schumacher, A. E., ... Murray, C. J. L. (2014). Global, regional, and national levels of neonatal, infant and under 5 mortality during 1990-2013: A systematic analysis for the Global Burden of Disease Study 2013. The Lancet, 384(9947), 957-979. http://dx.doi.org/10.1016/S0140-6736(14)60497-9

Wilkinson, R., \& Pickett, K. (2009). The spirit level. London: Penguin.

Williams, F. (1989). Social policy: A critical introduction - Issues of race, gender and class. Cambridge: Polity Press.

Williams, Z. (2012). The shadow state. A report about outsourcing of public services. London: Social Enterprise UK.

Wolfe, I., Macfarlane, A., Donkin, A., Marmot, M., \& Viner, R. (2014). Why children die: Death in infants, children and young people in the UK. Part A. London: Royal College of Paediatrics and Child Health / National Children's Bureau / British Association for Child and Adolescent Public Health.

Yngvesson, B. (2002). Placing the 'Gift Child' in transnational adoption. Law \& Society Review, 36(2), 227-256. http://dx.doi.org/10.2307/1512176 